\title{
MRI in amyloid $\beta$-related brain angiitis
}

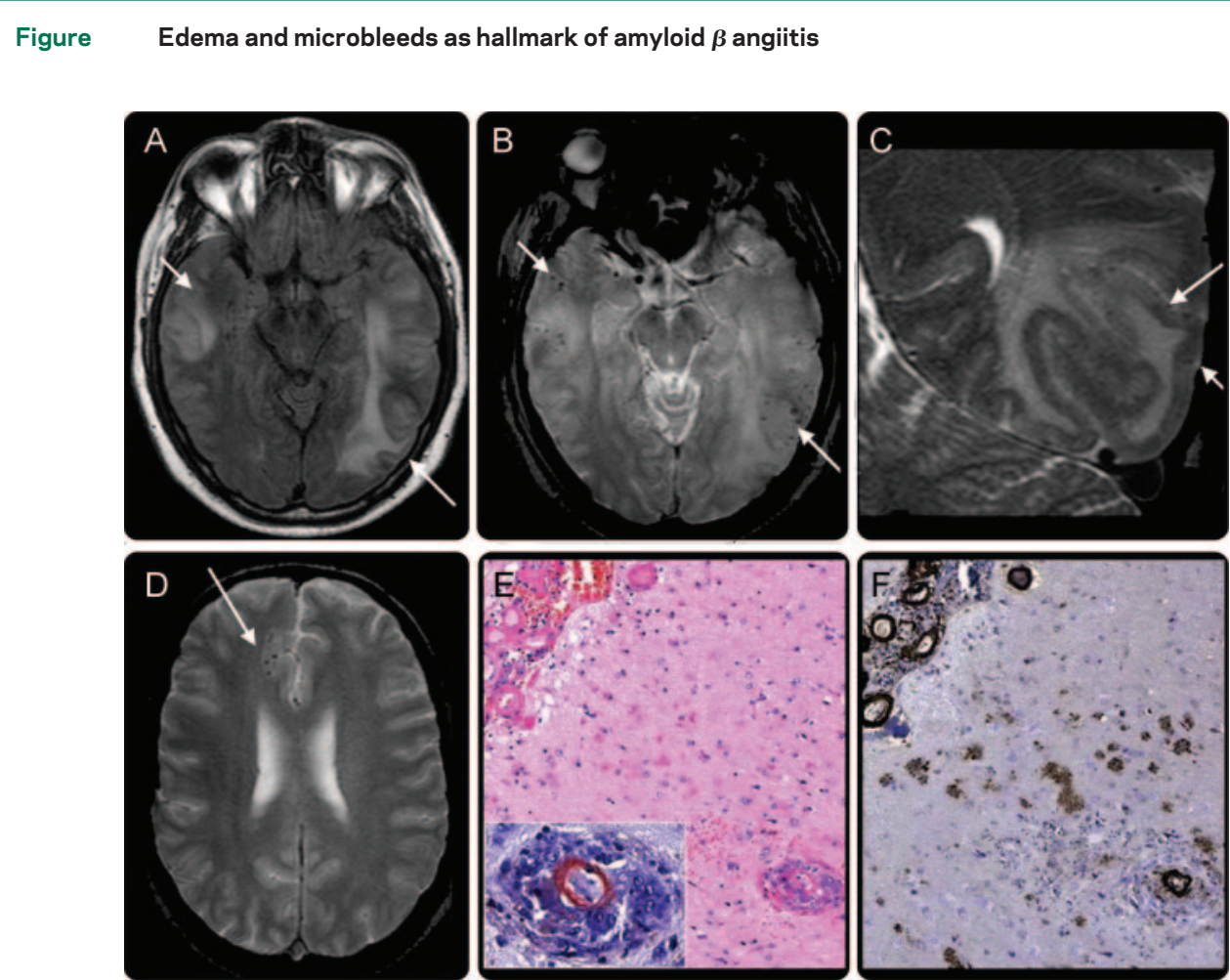

Fluid-attenuated inversion recovery (A), T2-weighted gradient echo (B), and high-resolution fast spin echo (C) images show bitemporal edema (A, B: arrows) and cortical microbleeds (punctuate areas marked by arrows in B and C). Microbleeds are present in edematous and nonedematous brain regions (D). Histopathology reveals inflammation and hyaline thickening of leptomeningeal and cortical vessel walls in hematoxylin-eosin stain (E), Congo red-positive vascular amyloid deposition with inflammation ( $E$, inset), $A \beta$ deposits (dark brown) in vessel walls, and diffuse cortical plaques ( $F, A \beta$ immunohistology).

A 52-year-old man presented with complex partial seizures. Fluid-attenuated inversion recovery MRI showed multifocal subcortical and cortical edema, predominantly in the left temporal lobe (figure, A). T2-weighted and gradient echo images showed multiple cortical microbleeds (figure, B-D). Right frontal brain biopsy revealed amyloid $\beta$-related angiitis showing leptomeningeal and cortical blood vessels with vascular $\beta$-amyloid deposition and perivascular/intramural inflammatory infiltrates with lymphocytes and often epithelioid appearing, sometimes multinucleated macrophages (figure, E) ${ }^{1,2}$ There were also diffuse cortical $\beta$-amyloid plaques without deposition of abnormal $\tau$-protein (figure, $\mathrm{F}$ ). That cortical microbleeds are present not only in edematous brain, but also in unaffected regions, likely reflects the pathophysiologic cascade of amyloid deposition followed by inflammation.

H.J. Tschampa, MD, P. Niehusmann, MD, M. Marek, MD, C.-A. Mueller, MD, K. Kuchelmeister, MD, PhD, H. Urbach, MD, PhD, Bonn, Germany

Disclosure: Dr. Tschampa, Dr. Niehusmann, Dr. Marek, Dr. Mueller, and Dr. Kuchelmeister report no disclosures. Dr. Urbach serves on the editorial board of Clinical Neuroradiology.

Address correspondence and reprint requests to Dr. Henriette J. Tschampa, Department of Radiology, Neuroradiology, University of Bonn, Sigmund-Freud-Strasse 25, D-53105 Bonn, Germany; Henriette.Tschampa@ukb.uni-bonn.de

1. Scolding NJ, Joseph F, Kirby PA, et al. A $\beta$-related angiitis: primary angiitis of the central nervous system associated with cerebral amyloid angiopathy. Brain 2005;128:500-515.

2. Marotti JD, Savitz SI, Kim WK, Williams K, Caplan LR, Joseph JT. Cerebral amyloid angiitis progressing to generalized angiitis and leukoencephalitis. Neuropathol Appl Neurobiol 2007;33:475-479. 


\section{Neurology}

\section{MRI in amyloid $\beta$-related brain angiitis}

H. J. Tschampa, P. Niehusmann, M. Marek, et al.

Neurology 2009;73;247

DOI 10.1212/WNL.0b013e3181ae7cd0

\section{This information is current as of July 20, 2009}

\section{Updated Information \&} Services

References

Permissions \& Licensing

Reprints including high resolution figures, can be found at: http://n.neurology.org/content/73/3/247.full

This article cites 2 articles, 0 of which you can access for free at: http://n.neurology.org/content/73/3/247.full\#ref-list-1

Information about reproducing this article in parts (figures,tables) or in its entirety can be found online at:

http://www.neurology.org/about/about_the_journal\#permissions

Information about ordering reprints can be found online: http://n.neurology.org/subscribers/advertise

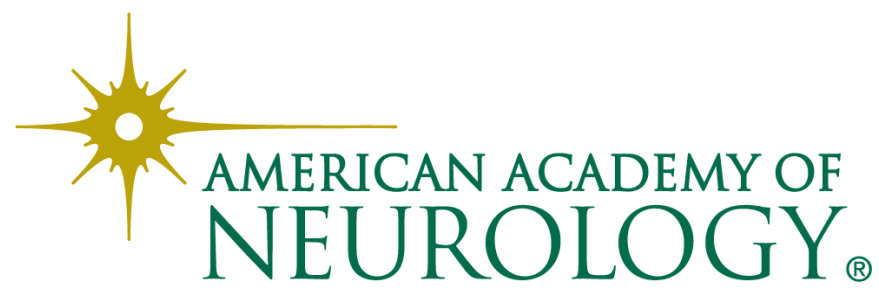

